\title{
ANALIZA I DOSKONALENIE JAKOŚCI NA PRZYKŁADZIE PRZEDSIĘBIORSTWA PRODUKCYJNEGO
}

\author{
Joanna Rosak-Szyrocka \\ Politechnika Częstochowska \\ Wydział Zarządzania
}

\begin{abstract}
Streszczenie: W artykule omówiono pojęcie jakości oraz doskonalenia w aspekcie konkurencyjności przedsiębiorstw i ich funkcjonowania. Obiektem badawczym jest przedsiębiorstwo produkcyjne zlokalizowane w województwie śląskim. Przeanalizowano problemy jakości występujące w przedsiębiorstwie w oparciu o wybrane narzędzia zarządzania jakością: diagram Ishikawy, a także diagram Pareto-Lorenza. Przedstawiono i omówiono podstawowe typy marnotrawstwa występujące w przedsiębiorstwie. Zaproponowano działania doskonalące oraz podkreślono znaczenie zasobów niematerialnych - pracowników przedsiębiorstwa.
\end{abstract}

Słowa kluczowe: jakość, doskonalenie, diagram Ishikawy, diagram Pareto-Lorenza

DOI: $10.17512 /$ znpcz.2017.4.1.04

„Jakość to zdolność organizacji do wprowadzenia klienta w stan zachwytu”

Prof. dr hab. Krystyna Cholewicka-Goździk

\section{Wprowadzenie}

Pojęcie jakości według Japończyków bezpośrednio związane jest z ciągłym doskonaleniem i z dążeniem do doskonałości. Efektem jest mniejsza liczba błędów i pomyłek oraz bardziej zadowolony klient (Czubała 2006, s. 288; Hamrol 2008, s. 547). Jak zauważa J. Priede (Priede 2012, s. 1466-1475), jakość jest bardzo ważnym i strategicznym komponentem konkurencyjności. Konkurencyjność przedsiębiorstw to zdolność do rozwoju, osiągania korzyści i zysków oraz budowania przewagi konkurencyjnej (Dobiegała-Korona, Kasiewicz 2000, s. 89-96; Ślusarczyk, Szajt 2013, s. 98). Przedsiębiorstwo, które chce być konkurencyjne na rynku krajowym bądź też zagranicznym, powinno nieustannie dążyć do nowoczesnych rozwiązań oraz powinno stawiać na wysoką jakość oferowanych produktów/usług. Ważne jest, aby dokonywać tego w każdej chwili i aspekcie swojego funkcjonowania. Zrozumiałe jest, że nie ma gotowych rozwiązań, czy też wzorcowych modeli postępowania, gwarantujących każdemu przedsiębiorstwu zdobycie trwałej przewagi konkurencyjnej oraz osiągnięcie sukcesu rynkowego.

Doskonalenie organizacji wydaje się dzisiaj jedną z kluczowych dróg poprawy działalności firmy, wzmocnienia jej potencjału, kreowania wartości dodanej, a w efe- 
kcie osiągnięcia zaplanowanych efektów (Kacała, Wierzbic 2015, s. 28-32; Ślusarczyk, Szajt 2013, s. 98). Jak zauważa A. Jazon (Jazon 2002, s. 269), doskonalenie procesów polega na: eliminacji działań, które nie tworzą wartości dodanej dla procesu, wprowadzeniu działań, które zwiększają efekty i zadowolenie odbiorców, a także takich, które poprawiają porozumiewanie się pomiędzy osobami uczestniczącymi w danym procesie, oraz wprowadzeniu zabiegów kontroli po to, żeby zmniejszyć ilość powstających błędów w poszczególnych etapach procesu lub też zabiegów zapobiegawczych. Z. Malara (Malara 2000) podkreśla, że doskonalenie polega na wyciąganiu wniosków z przeprowadzonych analiz i audytów, a następnie wprowadzeniu działań korygujących lub zapobiegawczych. Wszystkie kroki podejmowane są po to, aby sprostać wymaganiom i wyjść naprzeciw oczekiwaniom klientów.

Największe koszty przedsiębiorcy ponoszą nie w związku z jakością, sensu stricto, ale jej brakiem. Jakość stanowi wynik zamierzonych działań podejmowanych każdego dnia: wczoraj, dziś i jutro. Mając na uwadze to, jak istotne w uzyskiwaniu jakości jest konsekwentne działanie oparte na ewolucyjnym połączeniu wyciąganych wniosków z ,wczoraj”, realizacji „dobrze” tego, co mamy do wykonania „dziś” i planowaniu udoskonaleń na dzień ,jutrzejszy”, można uznać, że jakość ma znaczenie każdego dnia (Rysunek 1).

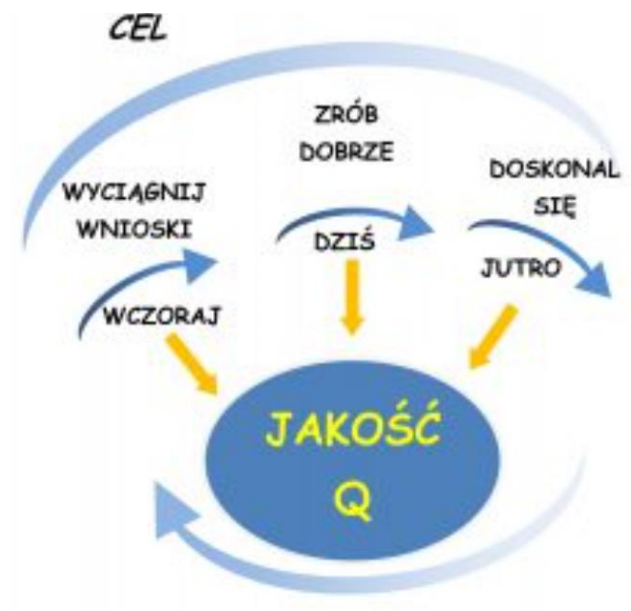

Rysunek 1. Znaczenie jakości wezoraj, dziś i jutro

Źródło: www.jakoscroku.pl

\section{Metodyka badań}

Obiektem badawczym jest przedsiębiorstwo zlokalizowane w województwie śląskim, produkujące użytkowe wyroby artystyczne. Pierwszy etap badań dotyczył analizy problemów jakościowych w przedsiębiorstwie. Podczas badań okazało się, że podstawowymi problemami w obiekcie badawczym są rozpadanie się gotowego haczyka oraz zbyt duża ilość przestojów w czasie pracy. Wymienione problemy zostały przeanalizowane za pomocą narzędzi zarządzania jakością: diagramu 
Ishikawy (rozpadanie się gotowego haczyka) oraz diagramu Pareto-Lorenza (zbyt duża ilość przestojów w czasie pracy). Drugi etap badań dotyczył przenalizowania organizacji procesu produkcji pojedynczego haczyka na kratę w przedsiębiorstwie, celem określenia typów marnotrawstwa.

\section{Analiza jakości z wykorzystaniem wybranych narzędzi zarządzania jakością}

\section{Diagram Ishikawy}

Obiekt badań to przedsiębiorstwo produkcyjne zajmujące się produkcją użytkowych wyrobów artystycznych, tzw. metaloplastyki, oraz ślusarstwem. W asortymencie firmy znajdują się wyroby, które są przeznaczone do urządzania sklepów z branży obuwniczej, odzieżowej oraz spożywczej. Obiekt badawczy produkuje artykuły do wyposażenia sklepów, np. stojaki, oraz drobne AGD, np. krajarki do makaronu. Zakład produkuje także akcesoria meblowe. Narzędziem zarządzania jakością często wykorzystywanym przez pracowników w połączeniu z burzą mózgów jest diagram Ihikawy, w celu dotarcia do lokalizacji przyczyny zaobserwowanego zjawiska (Borkowski 2013, s. 190). Diagram hierarchizuje pewne zjawiska i daje pogląd na problematyczne strefy. Na Rysunku 2 przedstawiono graficzną prezentację diagramu Ishikawy. Analiza Rysunku 2 pozwala stwierdzić, że największy wpływ na rozpadanie się gotowego haczyka jest związany z materiałem wykorzystywanym do jego produkcji. Niska jakość półfabrykatów bezpośrednio oddziałuje na trwałość gotowego wyrobu. Źle dobrane komponenty powodują, że haczyk na kratę ekspozycyjną rozpada się, jego części składowe są spojone nietrwale i nie mogą być dopuszczone do sprzedaży, co niesie za sobą koszty związane z naprawą bądź utylizacją. Inną ważną przyczyną mającą znaczący wpływ na rozpadanie się gotowego haczyka są ludzie - pracownicy. Zmęczenie, monotonia i brak motywacji obniża jakość pracy, a co za tym idzie zmniejsza efektywność przedsiębiorstwa. Pracownicy powinni być wszechstronni i przeszkoleni na tyle, aby móc przeprowadzić rotację na stanowiskach pracy. Takie działanie ma na celu zmniejszenie zmęczenia, ponieważ różnorodność zadań stawianych przed poszczególnymi osobami prowadzi do zwiększenia koncentracji i uwagi poświęconej wykonywanym zadaniom. Częsta zmiana stanowiska przeciwdziała również monotonii w pracy, ludzie stają się bardziej zaangażowani w powierzane im czynności. Prowadzi to do zmniejszenia błędów w czasie trwania procesu produkcyjnego.

\section{Diagram Pareto-Lorenza}

Diagram Pareto-Lorenza jest narzędziem, które umożliwia szeregowanie czynników mających wpływ na analizowany problem. Służy przede wszystkim do (Borkowski, Stofkova 2007, s. 122):

- eliminacji zjawisk występujących w przedsiębiorstwie najczęściej,

- eliminacji określonych przyczyn tworzących największe koszty,

- analizy częstości i wagi wystąpienia niezgodności. 
W badaniach zastosowano diagram do przeprowadzenia analizy przedsiębiorstwa metaloplastycznego. Problemem, jaki poddano analizie, jest zbyt duża ilość przestojów w czasie pracy. Wynikiem tego procesu było zidentyfikowanie następujących przyczyn razem z ilościami ich występowania (Tabela 1):

- spóźnienia w dostawach materiałów - 2,

- wady występujące w komponentach -4 ,

- awarie maszyn - 23,

- brak zamówień - 2,

- błędy pracowników - 15 ,

- źle skonstruowany harmonogram - 3 .

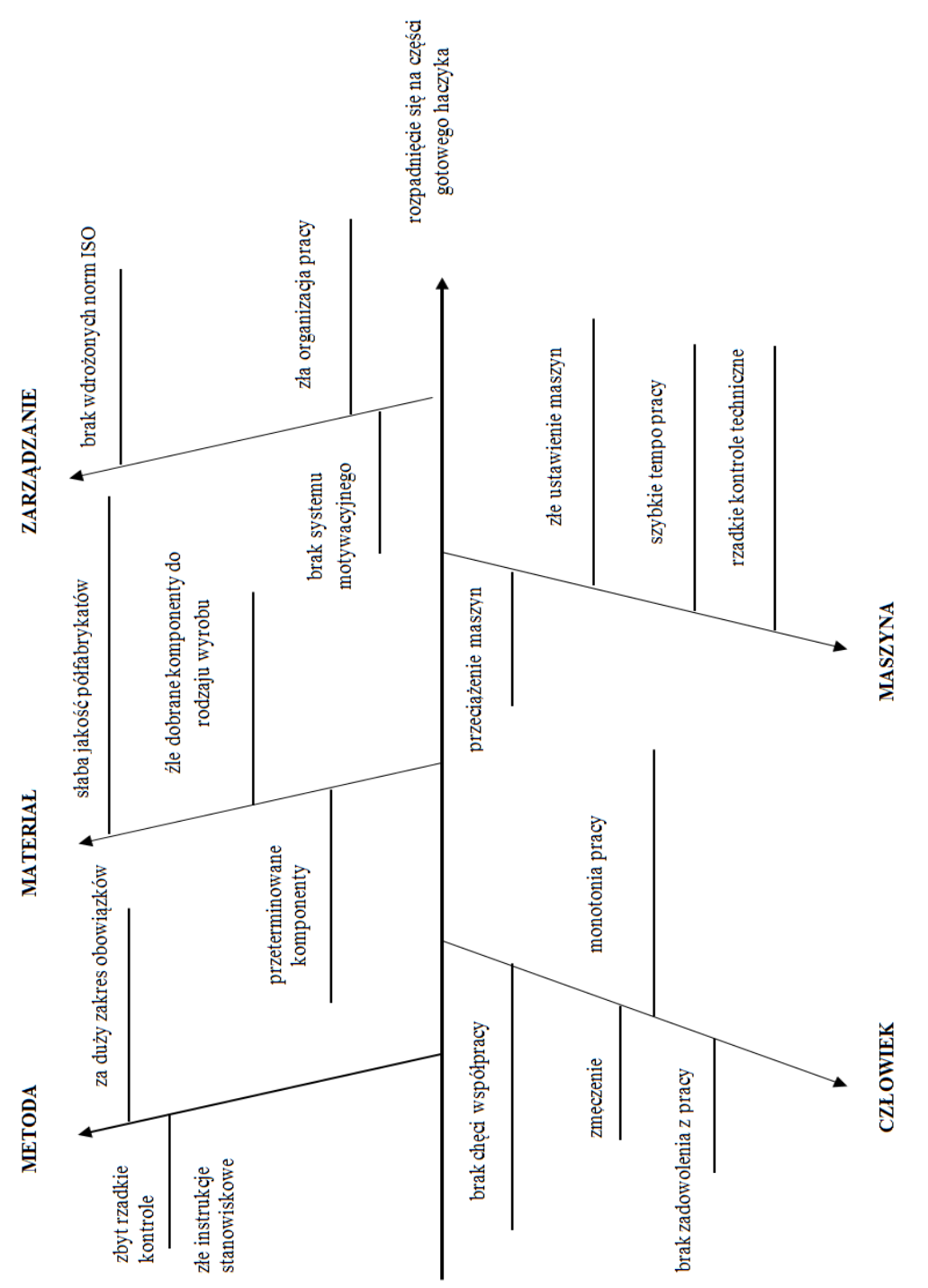

Rysunek 2. Identyfikacja przyczyn problemu za pomocą diagramu Ishikawy

Źródło: Opracowanie własne 
Jak wynika z Tabeli 1, najczęstszą przyczyną analizowanego błędu były awarie maszyn, najmniejszy udział w tym problemie miały opóźnienia w dostawach materiałów oraz brak zamówien. Na podstawie Tabeli 1 zbudowano diagram Pareto-Lorenza (Rysunek 3).

Tabela 1. Przyczyny występowania dużej ilości przestojów według częstości występowania

\begin{tabular}{|l|r|r|r|}
\hline \multicolumn{1}{|c|}{$\begin{array}{c}\text { Przyczyny } \\
\text { występowania }\end{array}$} & \multicolumn{1}{c|}{$\begin{array}{c}\text { Liczba } \\
\text { wystąpień }\end{array}$} & \multicolumn{1}{c|}{$\begin{array}{c}\text { Udzial } \\
\text { procentowy }\end{array}$} & $\begin{array}{c}\text { Wartość } \\
\text { skumulowana }\end{array}$ \\
\hline Awarie maszyn & 23 & 46,94 & 46,94 \\
\hline Błędy pracowników & 15 & 30,61 & 77,55 \\
\hline $\begin{array}{l}\text { Wady występujące } \\
\text { w komponentach }\end{array}$ & 4 & 8,16 & 85,71 \\
\hline $\begin{array}{l}\text { Źle skonstruowany } \\
\text { harmonogram }\end{array}$ & 3 & 6,12 & 91,84 \\
\hline $\begin{array}{l}\text { Spóźnienia } \\
\text { w dostawach mate- } \\
\text { riałów }\end{array}$ & 2 & 4,08 & 95,92 \\
\hline Brak zamówień & 2 & & 100,00 \\
\hline
\end{tabular}

Źródło: Opracowanie własne

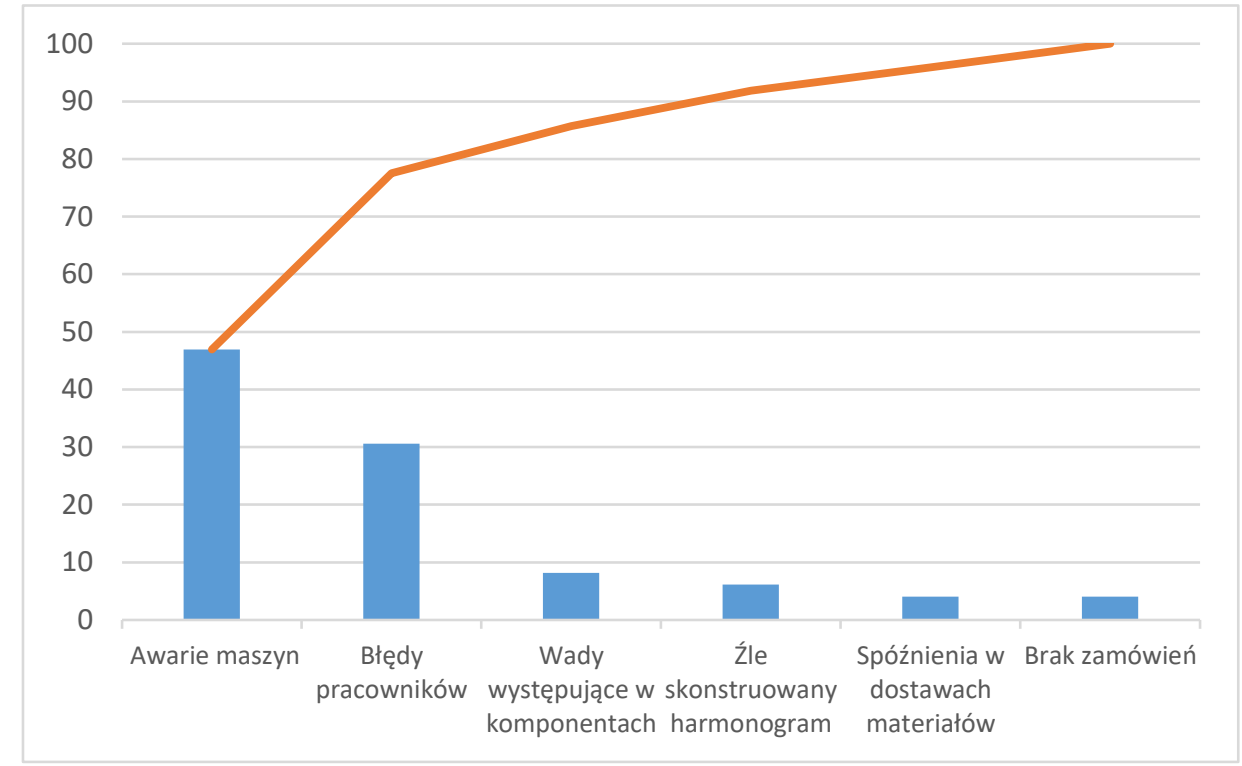

Rysunek 3. Diagram Pareto-Lorenza dla przyczyn występowania dużej ilości przestojów w czasie pracy

Źródło: Opracowanie własne

Analiza Rysunku 3 wykazuje, że 16,67\% przyczyn, na które składa się przyczyna ,awarie maszyn”, wywołuje w 46,94\% wszystkich przestojów w czasie pracy. 


\section{Identyfikacja miejsc marnotrawstwa}

Eliminacja marnotrawstwa jest obecnie jednym z najważniejszych celów nowoczesnych organizacji. W literaturze występuje 7 klasycznych rodzajów Mudy (Womack, Jones 2008, s. 568):

- Nadprodukcja - to produkcja wyrobów w liczbie niezgodnej z zamówieniem. Odbywa się ona w dwojaki sposób: wytwarzanie ilości większej niż potrzeba lub z wyprzedzeniem. Nadprodukcja jest sprzeczna z ideologią Just-in-Time i jest uważana za najbardziej niebezpieczny rodzaj Mudy, ponieważ prowadzi do powstawania kolejnych jej rodzajów, np. zapasów.

- Zapasy - to posiadanie większej niż zakładane minimum ilości półproduktów, surowców, wyrobów gotowych oraz pracy w toku. Obecność tego marnotrawstwa jest ściśle powiązana $\mathrm{z}$ nadprodukcją. Zapasy powodują, że środki finansowe są „zamrożone”, podczas gdy można by je wykorzystać w inny sposób. Poza tym stwarzają dodatkowe wydatki w postaci kosztów magazynowania i transportu oraz utylizacji zepsutych, uszkodzonych, zestarzałych produktów.

- Błędy - ten rodzaj marnotrawstwa dotyczy produkcji wadliwych wyrobów oraz niewłaściwego wykonania usług, a co za tym idzie przeprowadzenia ponadprogramowych inspekcji, powtórnej produkcji danego wyrobu, wymiany zareklamowanego wyrobu, naprawy lub też czasu, jaki jest potrzebny na wykonanie każdej z wymienionych czynności. Do tego rodzaju marnotrawstwa zalicza się wszystkie czynności, które musiały być wykonane powtórnie.

- Oczekiwanie - to zbędny przestój wyrobu w czasie tworzenia wartości dodanej lub oczekiwanie ludzi albo maszyn na niezbędne im do poprawnego wykonania zadań narzędzia, maszyny, informacje lub instrukcje.

- Nadmierne przetwarzanie - jest to ogół wykonanych czynności, które są zbędne przy wytwarzaniu produktu o określonych przez klienta parametrach. Dotyczy to niedostosowania maszyn do jakości wyrobu, czyli stosowanie zbyt drogich i zaawansowanych technologii, podczas gdy do uzyskania pożądanego efektu zupełnie wystarczającymi byłyby te proste i tanie.

- Zbędny transport - dotyczy zbędnego ruchu materiałów lub produktów na terenie przedsiębiorstwa, a także poza nim. Ten rodzaj marnotrawstwa powoduje dodatkowe wydatki na transport i zwiększa możliwość uszkodzenia lub zniszczenia wyrobów.

- Zbędny ruch - to ogół wykonywanych przez pracowników zbędnych czynności, wysiłku fizycznego podczas pracy, które najczęściej są związane ze złą organizacją lub nieprawidłowym ułożeniem stanowiska pracy. Zalecane jest tutaj zastosowanie metody $5 \mathrm{~S}$.

Standardowa lista podstawowych 7 strat jest wzbogacana o kolejny rodzaj Mudy, który został sklasyfikowany jako niewykorzystany potencjał pracowników. Przedsiębiorstwa często nie wysłuchują pomysłów pracowników, nie korzystają z ich kreatywności, talentu i kompetencji oraz w niewłaściwy sposób zarządzają ich czasem pracy. Często spotykanym jest stereotyp, że najlepsze pomysły są proponowane przez kierownictwo, a nie osoby bezpośrednio zaangażowane $\mathrm{w}$ dany proces (Marchwinski, Shook 2014). 
W pracy zidentyfikowano miejsca powstawania marnotrawstwa na hali produkcyjnej w czasie trwania procesu produkcji pojedynczego haczyka na kratę. Produkt ten jest jednym $\mathrm{z}$ wielu oferowanych przez przedsiębiorstwo. W zależności od rodzaju składanych zamówień pracownicy odpowiednio dobierają sprzęt i komponenty do procesu, mając przy tym do dyspozycji następujące pomieszczenia: biuro, halę główną, halę 2, lakiernię, magazyn wyrobów gotowych, narzędziownię, magazyn półproduktów, galwanizernię, maszynownię, halę do pakowania. Na Rysun$k u 4$ przedstawiono organizację przedsiębiorstwa wraz z oznaczeniami poszczególnych hal i maszyn. Analizując przebieg procesu produkcyjnego, zidentyfi-kowano kilka obszarów generujących straty oraz przedstawiono propozycje zmian. Odnaleziono pięć spośród siedmiu możliwych rodzajów strat. Drogi przepływu surowców oraz miejsca zidentyfikowanych obszarów marnotrawstwa zobrazowano na Rysun$k u$ 5. Linią ciągłą zaznaczono przepływ materiałów, natomiast linia przerywana oznacza przepływ informacji. Wyróżniono następujące typy marnotrawstwa w analizowanym obiekcie badawczym:

1. Zbędny transport - maszyny powinny stać na odwrotnych miejscach, aby zaoszczędzić na transporcie pomiędzy stanowiskami. Zmiana położenia maszyn nie wiąże się z żadnymi kosztami, ale może zwiększyć zyski wygenerowane z zaoszczędzonego czasu.

2. Nadprodukcja - tworzenie zapasów drobnych przedmiotów, które zalegają w magazynie - przedsiębiorstwo powinno stworzyć plany produkcji uwzględniające zapotrzebowanie na dany produkt. Często zdarza się, że pracownicy wytwarzają w nadmiarze przedmioty takie jak zawieszki czy haczyki, nie biorąc pod uwagę rzeczywistego zapotrzebowania na poszczególne elementy w określonym czasie. Wyroby te zajmują mało miejsca w magazynie, ale mimo wszystko zabierają przestrzeń, która mogłaby być wykorzystana w bardziej korzystnym celu.

3. Zapasy - zbyt duża ilość półproduktów zakupionych przez przedsiębiorstwo. Kierownik produkcji często zamawia półfabrykaty z wyprzedzeniem, nie biorąc pod uwagę zawartości magazynu i zapotrzebowania. Aby zminimalizować ten rodzaj marnotrawstwa, należałoby zmniejszyć ilość zamawianych materiałów, ale zwiększyć częstotliwość dostaw.

4. Oczekiwanie - zgrzewarka jest zbyt obciążoną maszyną potrzebną podczas wytwarzania większości produktów, dlatego też można by zakupić drugą lub udoskonalić harmonogram produkcji, aby równomiernie rozłożyć jej wykorzystanie.

5. Zbędny ruch (ludzi) - hala do pakowania powinna być zsynchronizowana $\mathrm{z}$ halą główną i otrzymywać zamówienia automatycznie. Można by do tego wykorzystać zintegrowany system zarządzania, który usprawniłby pracę ludzi i wyeliminował zbędne ruchy pracowników.

Większość zaproponowanych usprawnień nie wymaga nakładów finansowych, dlatego z powodzeniem może być zastosowana w obiekcie badawczym. 


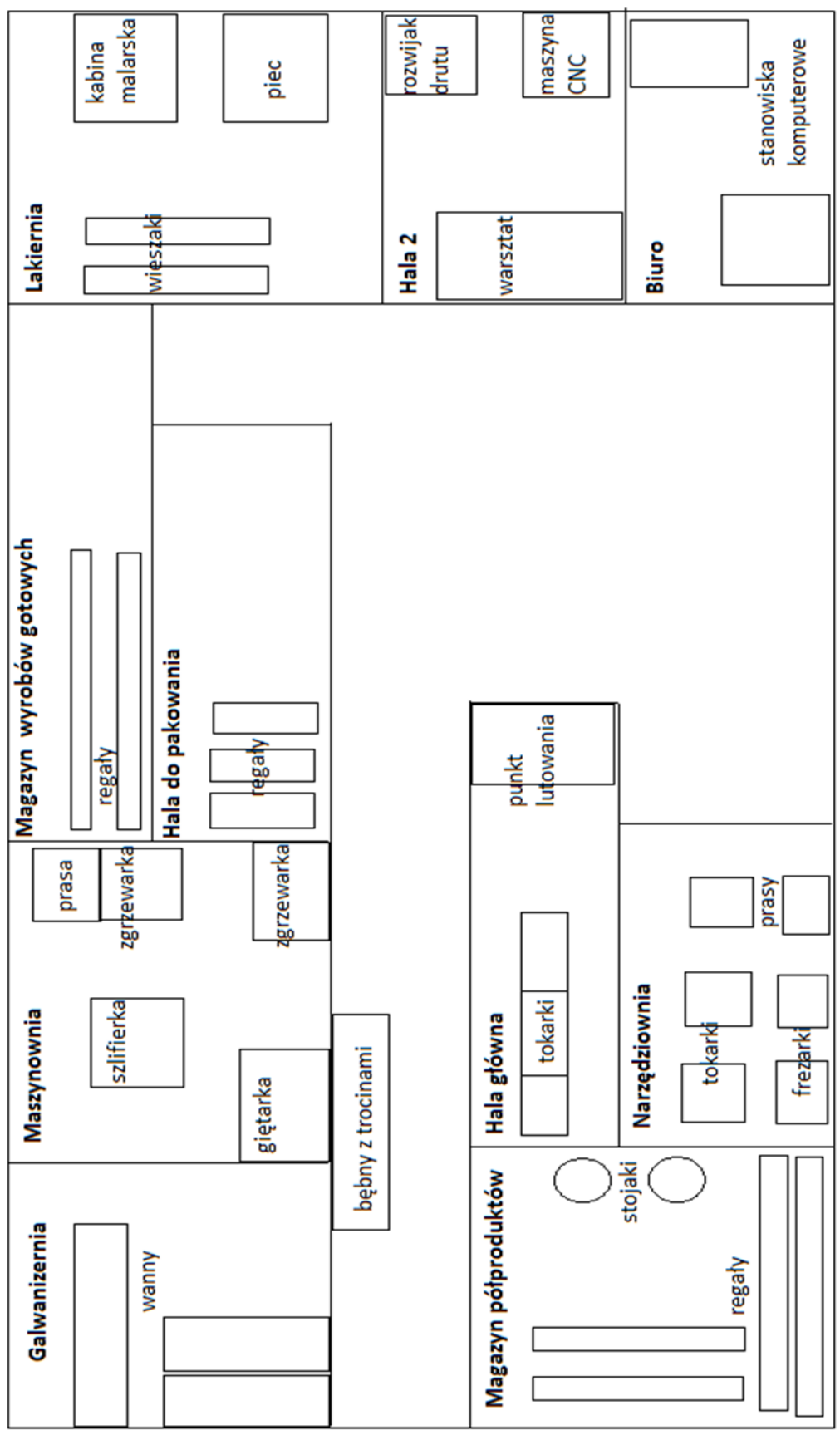

Rysunek 4. Organizacja przedsiębiorstwa

Źródło: Opracowanie własne 


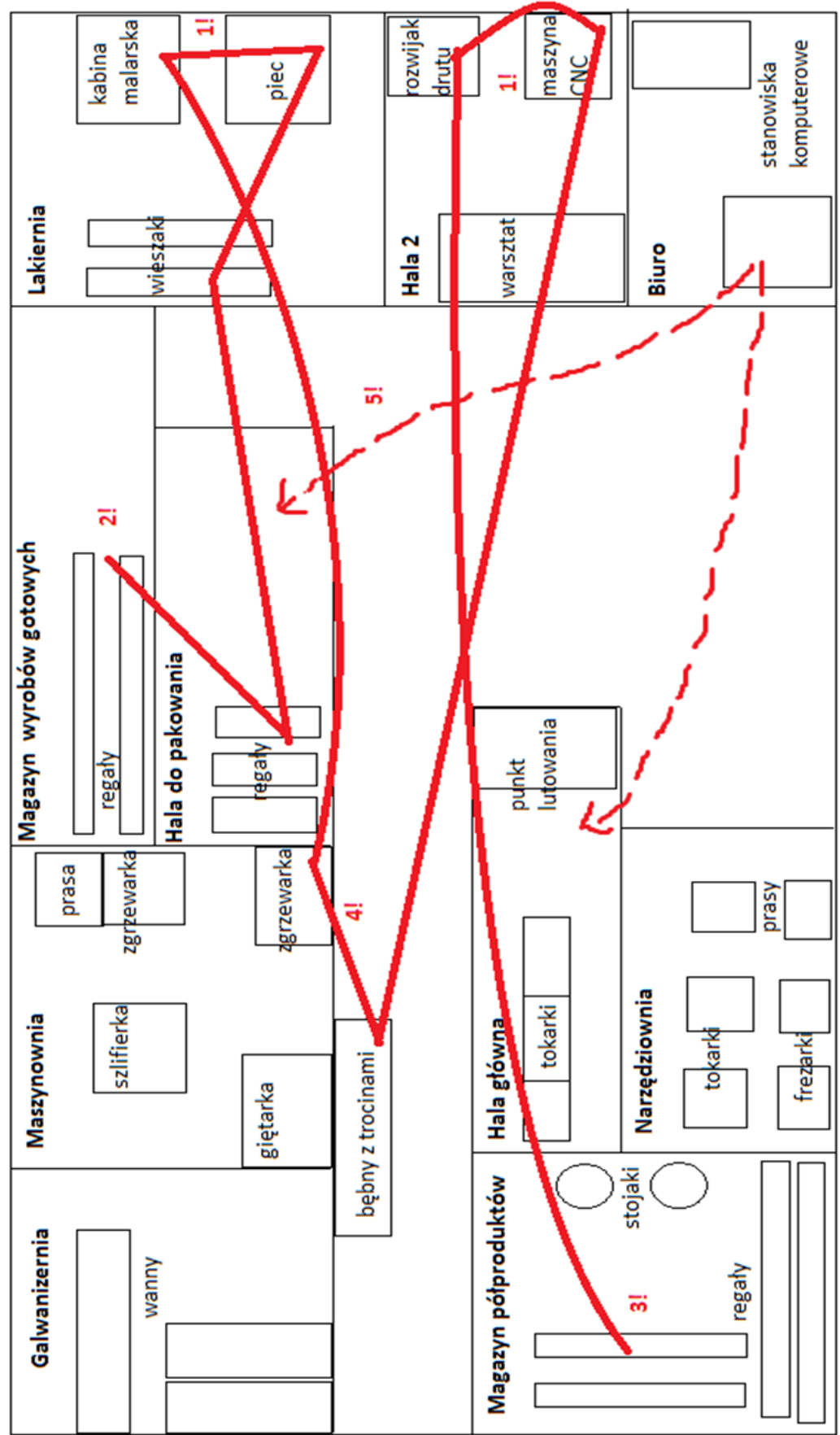

Rysunek 5. Organizacja przedsiębiorstwa z miejscami generującymi straty Źródło: Opracowanie własne 


\section{Podsumowanie}

Współcześnie szczególne znaczenie ma jakość usług świadczonych we wszystkich gałęziach gospodarki (Rosak-Szyrocka 2016, s. 166-183). Organizacje działające w biznesie ciągle poszukują nowych narzędzi, metod i systemów w celu maksymalizacji zysków i umocnienia swojej przewagi konkurencyjnej.

Doskonalenie wszystkich obszarów firmy jest ważne, gdyż umożliwia wzrost jej efektywności. Jak zauważa R. Wolniak (Wolniak 2014, s. 20-25), doskonalenie systemu zarządzania jakością przyczynia się do ograniczenia kosztów.

Analiza problemów jakościowych w oparciu o tradycyjne narzędzia zarządzania jakością pozwala stwierdzić, że w przypadku rozpadnięcia się gotowego haczyka, czego przyczyną jest materiał, należy skonsultować się z producentami, aby pomogli wybrać inny, być może lepszy rodzaj materiału. Dalsza analiza powala stwierdzić, że awarie maszyn można zniwelować poprzez częstsze dokonywanie przeglądów technicznych urządzeń po godzinach pracy przedsiębiorstwa. Czynność ta generuje koszty związane $\mathrm{z}$ wynagrodzeniem specjalistów, ale jednocześnie ogranicza straty czasu i pieniędzy związane bezpośrednio z postojem zakładu. Błędy pochodzące z zachowania pracowników również można zminimalizować poprzez skierowanie ich na dodatkowe szkolenia. Taki zabieg wnosi świeżość w spojrzeniu danej osoby na konkretny proces, pozwala na dostrzeżenie błędów z innej perspektywy i wprowadza nowe nawyki w zachowaniu załogi. Inwestycja w swoich podwładnych to doskonały zabieg dla podniesienia efektywności pracy. Potwierdzeniem rosnącego znaczenia wartości niematerialnych $\mathrm{w}$ wycenie organizacji są wyniki analiz zaprezentowanych przez Ocean Tomo - The Intellectual Capital Merchant Banc ${ }^{\mathrm{TM}} \mathrm{z}$ roku 2015. Na podstawie wyników przeprowadzonych analiz stwierdza się, iż największym atutem poddanych w badaniu analizie 500 największych korporacji na świecie są ich pracownicy - Rysunek 6. Przeprowadzone badania oparte zostały na indeksie S\&P 500, w skład którego wchodzi 500 przedsiębiorstw o największej kapitalizacji, notowanych na New York Stock Exchange i NASDAQ, są to głównie przedsiębiorstwa amerykańskie. Zmiana dotycząca wyceny 500 największych korporacji świata, której wartość przeszła ewolucję od udziału 83\% aktywów materialnych w jej wycenie w roku 1975 do wielkości $87 \%$ wartości niematerialnych w roku 2015, pozwala uznać, że to ludzie (pracownicy) są największą siłą napędową wartości każdej organizacji (Roszak 2016, s. 99).

Autorzy Hoag i Cooper (Hoag, Cooper 2006, s. 229) oraz Juchnowicz (Juchnowicz 2010, s. 35-49) twierdzą, że zasoby niematerialne są niejako wbudowane $\mathrm{w}$ wizerunek i reputację przedsiębiorstwa oraz relacje, jakie firma kształtuje ze swoimi klientami, pracownikami, dostawcami, partnerami i pozostałymi zainteresowanymi stronami, określanymi jako interesariusze. Zasoby niematerialne stały się decydującym czynnikiem konkurencyjności. 


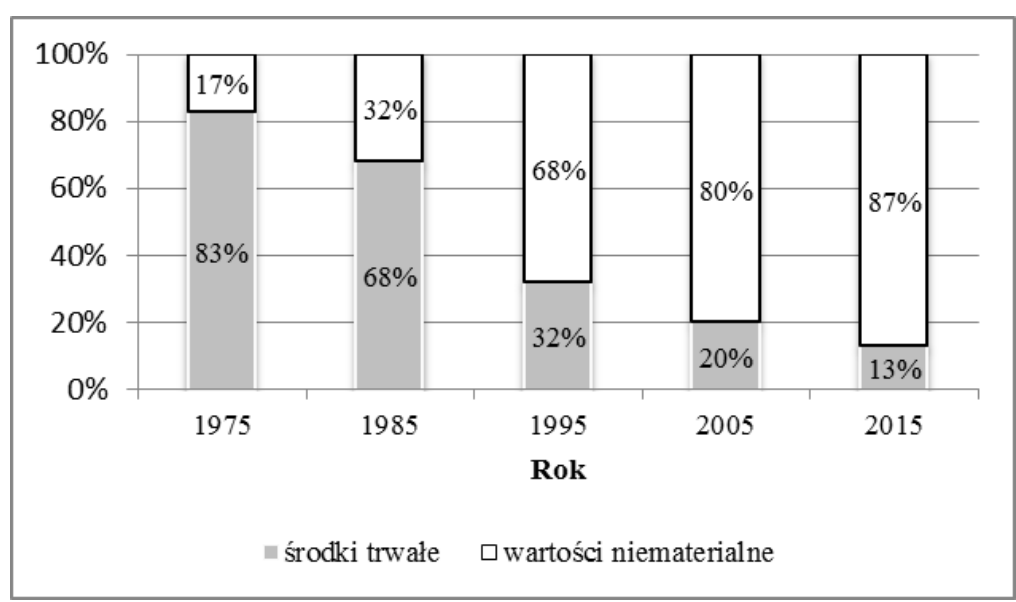

\section{Rysunek 6. Wyniki analiz zaprezentowanych przez Ocean Tomo - The Intellectual Capital Merchant Banc ${ }^{\mathrm{TM}} \mathrm{z}$ roku 2015}

Źródło: Ocean Tomo 2015

Analiza zagadnień związanych z marnotrawstwem pozwala stwierdzić, że wyszukiwanie i eliminacja różnych rodzajów marnotrawstwa mimo początkowych nakładów na inwestycje w końcowym efekcie wiąże się z dużymi oszczędnościami i zyskiem wynikającymi ze skracania czasu, cykli, dróg i ilości magazynowanych wyrobów gotowych i półfabrykatów.

\section{Literatura}

1. Borkowski S. (2013), Tradycyjne narzędzia zarządzania jakością. Teoria i praktyka, Oficyna Wydawnicza Stowarzyszenia Menedżerów Jakości i Produkcji, Częstochowa.

2. Borkowski S., Štofkova J. (2007), Praktyka zarządzania jakościa wyrobów i usług, Oficyna Wydawnicza Humanitas, Sosnowiec.

3. Czubała A. (2006), Ustugi $w$ gospodarce, [w:] Czubała A., Jonas A., Smoleń T., Wiktor W.J., Marketing ustug, Wolters Kluwer, Kraków, s. 13-41.

4. Dobiegała-Korona S., Kasiewicz B. (2000), Metody oceny konkurencyjności przedsiębiorstw, [w:] Kuciński K. (red.), Uwarunkowania konkurencyjności przedsiębiorstw w Polsce, Materiały i Prace IFGN, t. 79, Oficyna Wydawnicza SGH, Warszawa, s. 89-96.

5. Hamrol A. (2008), Zarządzanie jakościa z przykładami, Wydawnictwo Naukowe PWN, Warszawa.

6. Hoag B., Cooper C.L. (2006), Managing Value-Based Organizations: It's Not What You Think, Edward Elgar Publishing Limited, Northampton.

7. Jazon A. (2002), Doskonalenie zarządzania jakościa, Oficyna Wydawnicza Ośrodka Postępu Organizacyjnego, Bydgoszcz.

8. Juchnowicz M. (2010), Zarządzanie przez zaangażowanie. Koncepcja, kontrowersje, aplikacje, PWE, Warszawa.

9. Kacała J., Wierzbic A. (2015), Od systemów znormalizowanych do doskonałości bizneso$w e j$, ,Management Forum”, t. 3, nr 4, s. 32-39. DOI: 10.15611/mf.2015.4.05

10. Malara Z. (2000), Metody $i$ doskonalenie organizacji i zarządzania przedsiębiorstwem: z teorii i praktyki, Oficyna Wydawnicza Ośrodka Postępu Organizacyjnego, Bydgoszcz. 
11. Marchwinski C., Shook J. (2014), Lean Lexicon, Lean Enterprise Institute, Cambridge.

12. Ocean Tomo (2015), Annual Study of Intangible Asset Market Value from Ocean Tomo, LLC, http://www.oceantomo.com/2015/03/04/2015-intangible-asset-market-value-study (dostęp: 03.04.2017).

13. Priede J. (2012), Implementation of Quality Management System ISO 9001 in the World and Its Strategic Necessity, „Procedia - Social and Behavioral Sciences”, Vol. 58, 12 October, s. 1466-1475. DOI: 10.1016/j.sbspro.2012.09.1133

14. Rosak-Szyrocka J. (2016), Konkurencyjność usług medycznych w aspekcie systemów jakości, TNOiK „Dom Organizatora”, Toruń.

15. Roszak M. (2016), Zarządzanie wiedza jako czynnik kształtujący wartość dodana organizacji, [w:] Rosak-Szyrocka J., Sokół A., Roszak M. (red.), Materialne i niematerialne źródła tworzenia wartości - wybrane zagadnienia z zarzadzania $i$ ekonomii, Celje, Faculty of Logistics, University of Maribor, Maribor.

16. Ślusarczyk B., Szajt M. (2013), Globalizacja jako element wzrostu konkurencyjności, „Zeszyty Naukowe Politechniki Częstochowskiej. Zarządzanie”, nr 10, s. 98-110.

17. Ulewicz R., Mazur M. (2015), Doskonalenie transportu wewnętrznego z wykorzystaniem koncepcji LEAN - studium przypadku, „Przegląd Organizacji”, nr 7(906), s. 6-13.

18. Wolniak R. (2014), Korzyści doskonalenia systemów zarzązania jakościa opartych o wymagania normy ISO 9001:2008, „Problemy Jakości”, nr 3, s. 20-25.

19. Womack J.P., Jones D.T. (2008), Lean Thinking - szczupte myślenie, Wydawnictwo ProdPublishing.com, Wrocław.

20. www.jakoscroku.pl (dostęp: 21.01.2017).

\title{
ANALYSIS AND QUALITY IMPROVEMENT IN THE PRODUCTION COMPANY EXAMPLE
}

\begin{abstract}
The article discusses the quality concept and improvement in terms of companys' competitiveness and its operations. The research object is a production company located in Silesia province. We analyzed the quality problems occurring in the company based on the selected quality management tools: Ishikawa diagram and the Pareto-Lorenz. It was presented and discussed basic types of waste occurring in the enterprise. It was proposed improvement actions and highlights the importance of immaterial resources - the company's workers.
\end{abstract}

Keywords: quality, improvement, Ishikawa diagram, Pareto-Lorenz diagram 